\title{
Özefagus karsinomunun abse şeklinde prezente olan kalvaryal metastazının radyolojik bulguları
}

\author{
Radiological findings of calvarial metastasis of esophageal cancer with abscess \\ formation
}

\author{
Emre Emekli, Berat Acu, Durmuş Etiz
}

Gönderilme tarihi: 06.07.2019

Kabul tarihi: 29.11.2019

\section{Özet}

Özefagus kanseri dünya çapında en fazla bildirilen kanserlerden biridir. En sık uzak metastaz yaptığı organlar sırasıyla karaciğer, akciğer ve kemiklerdir. Beklenmedik metastazları seri çalışmaları ile araştırılmıştır. Bu çalışmada skuamöz hücreli özefagus kanserinin abse şeklinde prezente olan kalvaryal metastazının radyolojik bulgularını sunmayı amaçladık. 55 yaşında kadın hasta disfaji şikayeti ile Gastroenteroloji polikliniğine başvurdu. Bilgisayarlı tomografide (BT) özefagus orta-distal kesiminde asimetrik duvar kalınlık artışı ve proksimalinde dilatasyon saptandı. Yapılan kontrastı beyin manyetik rezonans görüntüleme (MRG) tetkikinde sağ paryetal kemikte yoğun içerikli kistik görünüm saptandı. Girişimsel radyoloji ünitesinde yoğun içerikli kistik görünüm ultrasonografi(US) ile aspire edildi. Aspire edilen içeriğin pürülan vasıfta olduğu görüldü. Sitopatolojik değerlendirme ise skuamöz hücreli karsinom metastazı şeklinde raporlandı. Olgumuzda literatürde bildirildiğinden farklı olarak metastatik kitlenin santrali MRG ve US incelemede yoğun içerikli koleksiyon şeklinde görüntüleme özellikleri göstermekteydi. Yaptığımız ultrasonografi eşliğinde aspirasyonda metastatik kitlenin büyük bölümü pürülan vasıftaydı. Kalvaryal metastatik lezyonlar genellikle ağrısız lokal şişliğe neden olurlar. Bu nedenle kalvaryumda kitle ile başvuran hastalarda, hastanın klinik bulguları ile ilişkili metastatik kitleler ayırıcı tanıda düşünülmelidir.

Anahtar kelimeler: Özefagus, kalvaryum, metastaz, abse, manyetik rezonans görüntüleme.

Emekli E, Acu B, Etiz D. Özefagus karsinomunun abse şeklinde prezente olan kalvaryal metastazının radyolojik bulguları. Pam Tıp Derg 2020;13:219-223.

\begin{abstract}
Esophageal cancer is one of the most reported cancers worldwide. The most common organs of distant metastasis are the liver, lungs and bones, respectively. Unexpected metastases were only investigated in case series. In this study, we aimed to present radiological findings of calvaryal metastasis of squamous cell esophageal cancer with abscess formation. A 55-year-old woman was admitted to Gastroenterology outpatient clinic with the complaint of dysphagia. In the computed tomography (CT), increased asymmetric wall thickness and proximal dilatation were detected in the mid-distal section of the esophagus. Contrast-enhanced cerebral magnetic resonans imaging (MRI) showed a cystic appearance in the right parietal bone.Cystic appearance was aspirated by ultrasonography (US) in the interventional radiology unit. Aspirated material was purulent. Cytopathological evaluation was reported as squamous cell carcinoma metastasis. In our case, unlike reported in the literature, the metastatic mass showed collection with dense content at the center on MRI and US examination. We observed that most of the metastatic mass was purulent in ultrasonography-guided aspiration. Calvarial metastatic lesions usually cause painless local swelling. Therefore, patients admitted with a calvarial mass, metastatic masses associated with the patient's clinical findings should be considered in the differential diagnosis.
\end{abstract}

Key words: Esophagus, calvarium, metastasis, abscess, magnetic resonance imaging.

Emekli E, Acu B, Etiz D. Radiological findings of calvarial metastasis of esophageal cancer with abscess formation. Pam Med J 2020;13:219-223.

Emre Emekli, Arş. Gör. Dr. Eskişehir Osmangazi Üniversitesi Tıp Fakültesi Radyoloji Anabilim Dalı, ESKiŞEHiR, e-posta: emreemekli90@gmail.com (orcid.org/0000-0001-5989-1897) (Sorumlu Yazar)

Berat Acu, Doç. Dr. Eskişehir Osmangazi Üniversitesi Tıp Fakültesi Radyoloji Anabilim Dalı, ESKişEHIR, e-posta: bacu@ogu.edu.tr (orcid.org/00000001-9590-1052)

Durmuş Etiz, Prof. Dr. Eskişehir Osmangazi Üniversitesi Tıp Fakültesi Radyasyon Onkolojisi Anabilim Dalı, ESKiŞEHiR, e-posta: detiz@ogu.edu.tr (orcid.org/0000-0002-2225-0364) 


\section{Giriş}

Özefagus kanseri dünya çapında kanser vakalarının \%3,2'sini ve kansere bağlı ölümlerin $\% 5,3$ 'ünü meydana getirir [1]. Beş yıllık sağ kalımı literatürde $\% 16,6-20,5$ oranlarında bildirilmiş olup, mortalite oranı yüksektir [2].

Özefagus kanserinin adenokarsinom ve skuamöz hücreli karsinom olmak üzere iki temel histolojik tipi mevcuttur. Skuamöz hücreli tip, özefagus kanserlerinin çoğunluğunu meydana getirir [3]. En sık uzak metastaz yaptığı organlar sırasıyla karaciğer, akciğer ve kemiklerdir. Beklenmedik metastazlar sadece sporadik vaka raporları ve vaka seri çalışmaları ile araştırılmıştır. $\mathrm{Bu}$ nedenle kesin insidansları bilinmemektedir [4]. Bu çalışmada 55 yaşındaki kadın hastada skuamöz hücreli özefagus kanserinin abse şeklinde prezente olan kalvaryal metastazının radyolojik bulgularını sunmayı amaçladık.

\section{Olgu sunumu}

55 yaşında kadın hasta disfaji şikayeti ile Gastroenteroloji polikliniğine başvurdu. Daha önceden bilinen akalazya tanısı olan hastaya, 4 yı önce Heller miyotomi operasyonu uygulanmıştı. Çekilen kontrol bilgisayarlı tomografi (BT) tetkikinde özefagus orta-distal kesiminde asimetrik kitlesel duvar kalınlık artışı ve bu seviye proksimalinde özefagusta dilatasyon saptandı. Toraks ve abdomen BT tetkiklerinde metastazı düşündürecek bulgu mevcut değildi. Aynı zamanda sağ pariyetal bölgede travma öyküsü ve şişlik tanımlayan hastanın çekilen pozitron emisyon tomografibilgisayarlı tomografi (PET-BT) tetkikinde ise, özefagusun T5-T6 seviyesine uyan kesiminde fokal hipermetobolik odak ve sağ pariyetal kemikte yaklaşık $2 \mathrm{~cm}$ çapında hipermetabolik odak saptandı. Bunun üzerine yapılan kontrastlı beyin manyetik rezonans görüntüleme (MRG) tetkikinde sağ pariyetal kemikte $4 \times 3 \mathrm{~cm}$ boyutunda dış tabulayı ve iç tabulayı destrükte eden, durayı geçerek giral yüz komşuluğuna ve skalp altına uzanan, T1 ağırlıklı serilerde seviyelenme veren, izointens-hafif hiperintens, T2 ağırlıklı serilerde hiperintens olarak gözlenen, postkontrast serilerde ise, kontrast tutulumu gösteren duvar yapısının olduğu yoğun içerikli kistik olabilecek görünüm saptandı(Resim1, Resim2, Resim 3a, 3b. Resim 4). Difüzyon görüntülerde tanımlanan lezyon difüzyon kısıtlaması göstermekteydi (Resim 5). Histopatolojik tanı için girişimsel radyoloji ünitesinde refere edilen hastanın yapılan lezyona yönelik ultrasonografi (US) incelemesinde yaklaşık $4 \times 2,5 \mathrm{~cm}$ boyutunda heterojen ekojenitede ve santrali yoğun içerikli koleksiyon izlendi. Bu yoğun içerikli koleksiyondan US eşliğinde perkütan örnekleme amaçlı lezyon bölgesinin steril şartlarda gerekli arıtım ve örtümünü takiben lokal anestezik uygulanarak ultrasonografi eşliğinde 18G spinal iğne ile lezyon içine ulaşıldı. Tüm içerik aspire edildi. Aspire edilen içeriğin pürülan vasıfta olduğu dikkati çekti. Elde edilen örnekler sitopatolojik ve mikrobiyolojik değerlendirme için mikrobiyoloji ve patoloji laboratuvarına gönderildi. Mikrobiyolojik incelemede patojen bakteri üremedi. Sitopatolojik değerlendirme ise, skuamöz hücreli karsinom (SCC) metastazı şeklinde raporlandı.

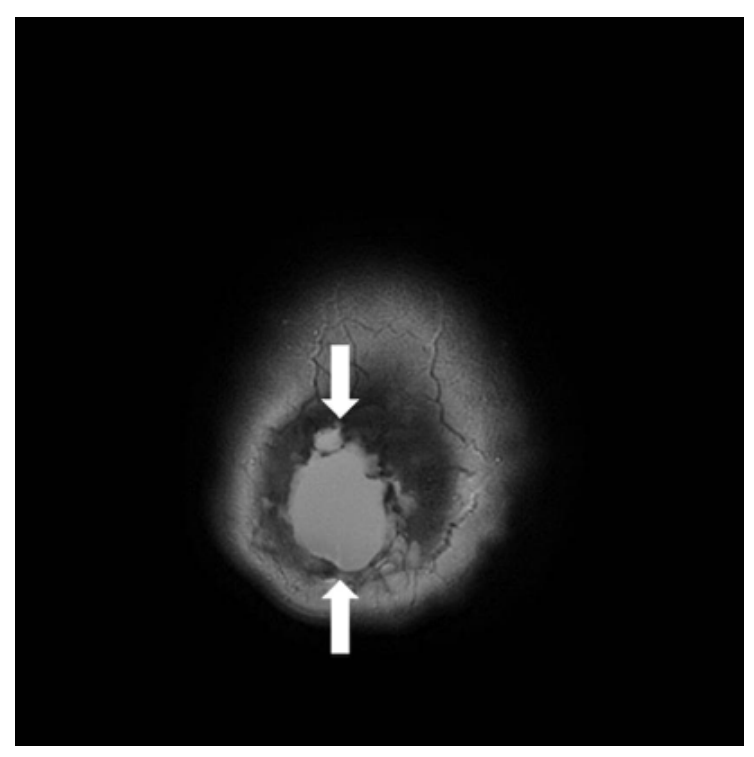

Resim 1. Verteks düzeyinden geçen aksiyel FSE-T2 ağırlıkı görüntülerde hiperintense olarak izlenen kistik lezyon izlenmektedir.(oklar) 


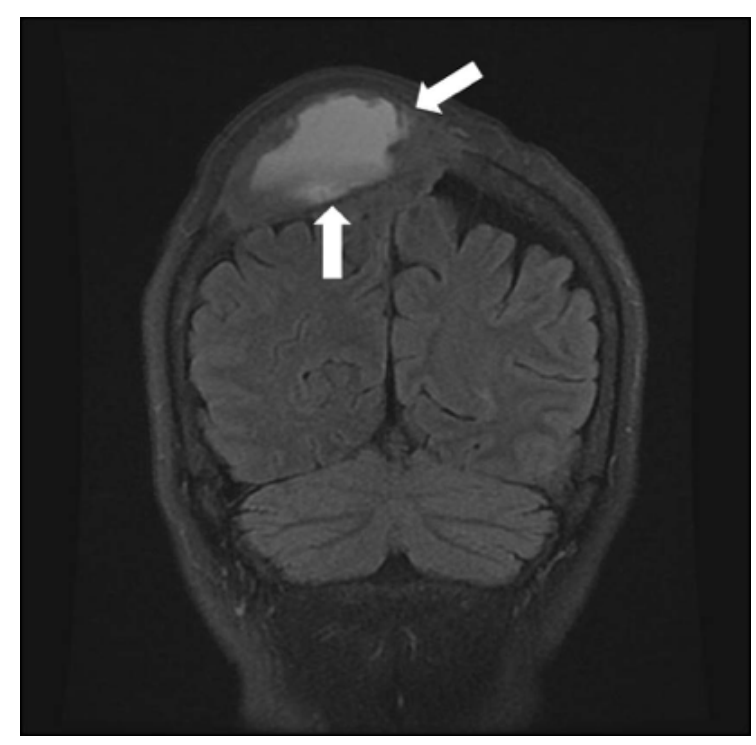

Resim 2. Koronal FLAîR görüntülerde sağ pariyetal kemikte verteks düzeyinde kalvaryal tabulayı destrükte eden santrali kistik asimetrik kalınlaşan duvarı izlenen kitle lezyonu izlenmektedir.(oklar)

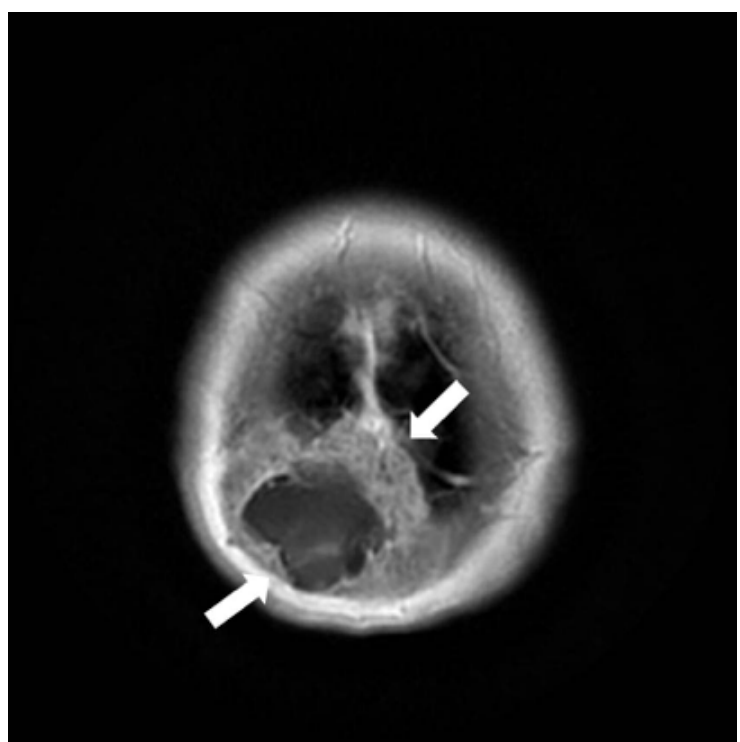

Resim 3a. Verteks düzeyinden geçen aksiyel post-kontrast T1 ağırlıklı görüntüde santrali kistik asimetrik kalınlaşma şeklinde izlenen duvar kontrastlanması gösteren lezyon dikkati çekmektedir.(oklar)

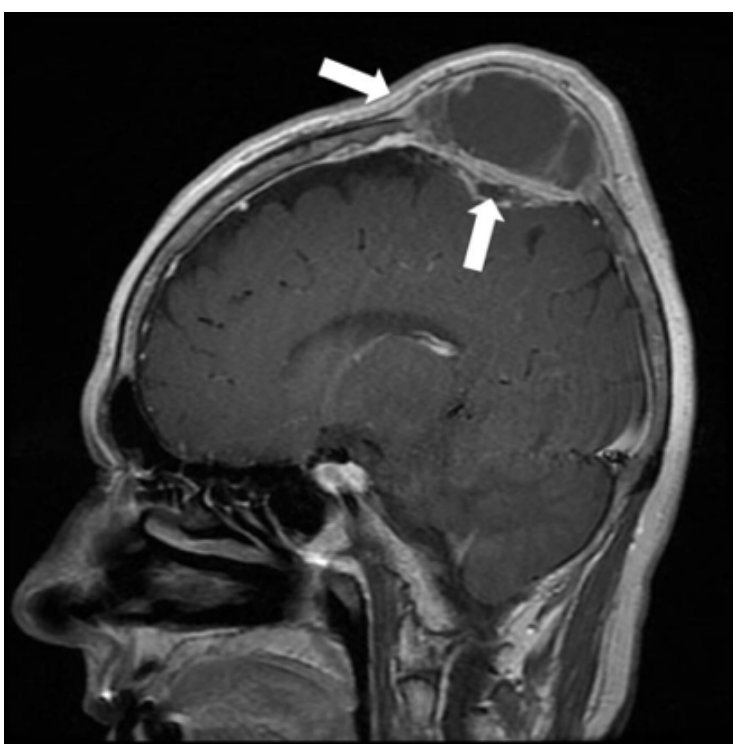

Resim 3b. Sagital post-kontrast yağ baskılı T1 ağırlıklı görüntüde verteks düzeyinde kalvaryal tabulayı destrükte ederek inferiorda dural basılanma ile serebral dokuyu indante eden süperiorda ise skalp altına uzanan yoğun periferal kontrastlanma gösteren kistik kitle lezyonu izlenmektedir.(oklar)

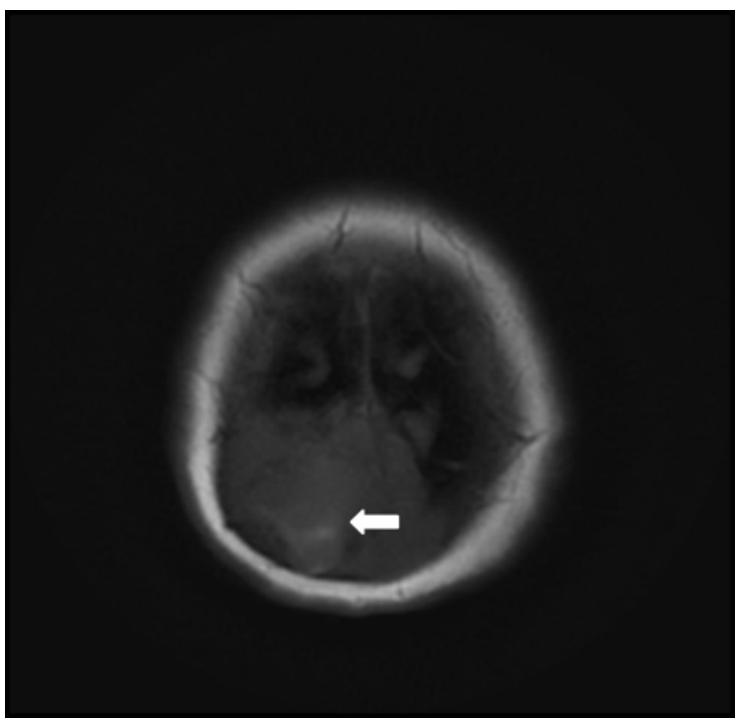

Resim 4. Verteks düzeyinden geçen aksiyel T1 ağırlıklı görüntüde sıvı-sıvı seviyelenmesi izlenmektedir.(ok) 


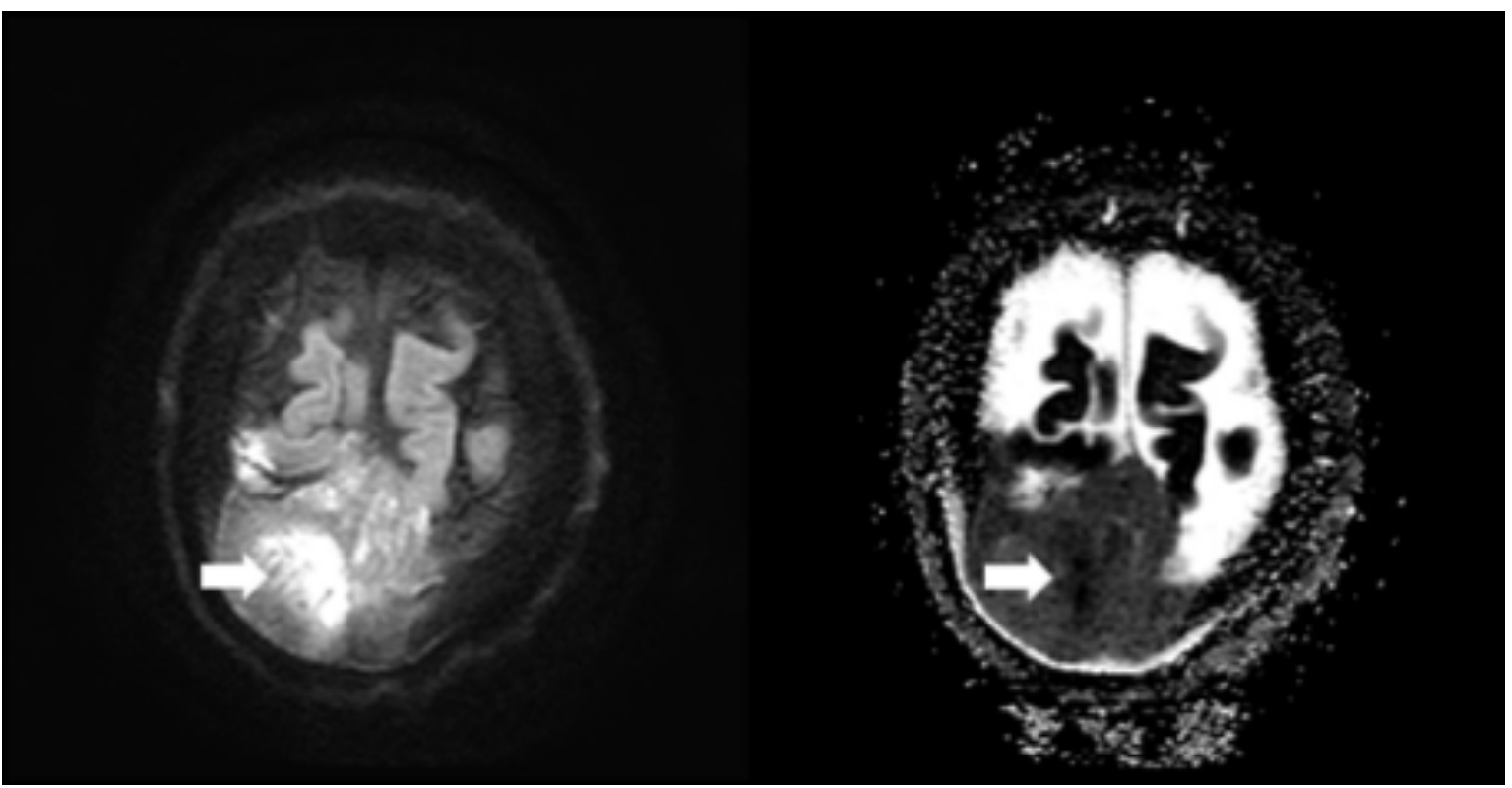

Resim 5. Verteks düzeyinden geçen aksiyel difüzyon görüntüde ve ADC haritasında santral kesimde difüzyon kısıtlaması mevcuttur.(oklar)

\section{Tartışma}

Özefagus kanseri olan hastaların prognozları, diğer kanserlerde olduğu gibi tanı anındaki evre ile yakından ilişkilidir. Özefagus kanseri evreleme kriterleri arasında lokal invazyon derinliği, bölgesel lenf nodu tutulumu ve uzak metastaz yer almaktadır. Ancak özefagus kanserli hastalar, genellikle lokal ilerlemiş veya metastatik kitle ile başvururlar [5]. Hastaların yaklaşık \%50'sinde, tanı anında uzak lenf nodlarına veya uzak organlara metastaz mevcuttur. Metastatik kanserin prognozu kötüdür ve beş yıllık sağ kalım oranı $\% 5$ 'in altındadır [6].

Cerrahi rezeksiyon, uzak metastaz veya lokal invazif olmayan hastalar için en iyi tedavi seçeneğidir. Günümüzde özefagus kanserli bir hastanın cerrahi, kemoterapi veya kemoradyoterapi kombinasyonu ile tedavi edilmesinin gerekliliğini belirlemek için BT, endoskopik US ve PET-BT'nin kombine kullanımı önerilmektedir [5]. Özefagus kanserinin, sıklıkla akciğer, plevra, karaciğer, periton ve adrenal bezlerde uzak metastaza neden olabileceği bilinmektedir. Ancak kemiklere metastaz nadirdir [6]. Kalvaryum metastazları, tüm kanser türlerine ait metastaz vakaları içinde nadir görülürler. Bu nedenle kalvaryal metastazların gerçek insidansı bilinmemektedir. Literatürdeki olgu sunumlarında akciğer, prostat ve tiroid kanserleri başta olmak üzere tüm kanser türlerinin kalvaryum metastazları tanımlamıştır [8]. Yapılan bir çalışmada literatürde bildirilen 175 kalvaryum metastazından sadece 5 tanesinin özefagus kanseri metastazına ait olduğu tespit edilmiştir [9]. Shaheen ve ark. [10] tarafından yapılan bir çalışmada, 164 beklenmeyen bölgelere metastaz yapan özefagus kanserleri içinde, 11 tane kalvaryum metastazı olduğu bildirilmiştir. Stark ve ark. [11] yaptıkları bir çalışmada, kalvaryal metastazların, primer kafatasındaki tümörlerden ve tümör benzeri lezyonlardan ayırt edici karakteristik özelliklere sahip olduğunu iddia etmişlerdir. Buna göre, kalvaryumdaki metastazlar tipik olarak ekspansil, osteolitik, hipervasküler lezyonlardır. MRG tetkiklerinde gadolinyumlu incelemelerde orta derecede kontrastlanma gösteren ve T2 ağırlıklı görüntülerde ise izointens veya hipointens lezyonlar olarak izlenirler. Metastatik lezyonlar genellikle ağrısız lokal şişliğe neden olurlar. Ancak nadiren nörolojik disfonksiyona neden olabilecekleri bildirilmiştir [11].

Bizim olgumuzda çekilen MRG de literatürde bildirildiğinden farklı olarak metastatik kitlenin santrali MRG ve US incelemede nekrotik -yoğun içerikli koleksiyon şeklinde görüntüleme özellikleri göstermekteydi. Yaptığımız ultrasonografi eşliğinde aspirasyonda metastatik kitlenin büyük bölümü pürülan SıVı vasfında idi. Aspirasyon sonrası kitle boyutu belirgin olarak azaldı. Kalvaryal metastazlar genellikle 
semptoma neden olmazlar [12]. Ancak literatürde özefagus karsinomundan kaynaklanan kalvaryumdaki metastaza ikincil gelişen akut epidural hematom olgusu bildirilmiştir. Bizim olgumuzda ise pariyetal bölgede travma sonrası lokal şişlik tanımlanmakta idi. Kalvaryal metastaz olgularında ekstradural veya intratümöral kanama ve buna ikincil nörolojik sonuçlar nedeniyle tedavi düşünülmelidir. Cerrahi, metastatik hastalarda klinik gereklilik halinde metastaz için güvenilir ve tedavi edicidir $[11,12]$.

Kalvaryal metastazlar nadir görülmekle birlikte özefagus kanserlerinde semptomlar gelişmeden önce tespit edilebilir. Bu nedenle kalvaryumda kitle ile başvuran hastalarda, hastanın klinik bulguları ile ilişkili metastatik kitleler ayırıcı tanıda düşünülmelidir.

Çıkar ilişkisi: Yazarlar çıkar ilişkisi olmadığını beyan eder.

\section{Kaynaklar}

1. Fitzmaurice C, Dicker D, Pain A, et al. The global burden of cancer 2013. JAMA Oncol 2015;1:505527. https://doi.org/10.1001/jamaoncol.2015.0735

2. Noone AM, Cronin KA, Altekruse SF, et al. Cancer incidence and survival trends by subtype Using data from the surveillance epidemiology and End Results Program, 1992-2013. Cancer Epidemiol Biomarkers Prev 2017;26:632-641. https://doi.org/10.1158/10559965.EPI-16-0520.

3. Quint LE, Hepburn LM, Francis IR, Whyte RI, Orringer MB. Incidence and distribution of distant metastases from newly diagnosed esophageal carcinoma. Cancer 1995;76:1120-1125. https://doi. org/10.1002/1097-0142(19951001)76:7<1120::aidcncr2820760704>3.0.co;2-w

4. Kim TJ, Kim HY, Lee KW, Kim MS. Multimodality assessment of esophageal cancer: preoperative staging and monitoring of response to therapy. Radiographics 2009;29:403-421. https://doi. org/10.1148/rg.292085106

5. Enzinger PC, Mayer RJ. Esophageal cancer. N Engl J Med 2003;349:2241-2252. https://doi.org/10.1056/ NEJMra035010

6. Chen $\mathrm{YH}$, Huang $\mathrm{CH}$. Esophageal squamous cell carcinoma with dural and bone marrow metastases. World J Gastroenterol 2014;20:12691-12695. https:// doi.org/10.3748/wjg.v20.i35.12691

7. Laigle-Donadey F, Taillibert S, Martin Duverneuil N, Hildebrand J, Delattre JY. Skull-base metastases. J Neurooncol 2005;75:63-69. https://doi.org/10.1007/ s11060-004-8099-0
8. Mitsuya K, Nakasu $\mathrm{Y}$, Horiguchi S, et al. Metastatic skull tumors: MRI features and a new conventional classification J Neurooncol 2011;104:239-245. https:// doi.org/10.1007/s11060-010-0465-5

9. Shaheen O, Ghibour A, Alsaid B. Esophageal cancer metastases to unexpected sites: a systematic review. Gastroenterol Res Pract 2017;2017:1657310. https:// doi.org/10.1155/2017/1657310

10. Stark AM, Eichmann T, Mehdorn HM. Skull metastases: clinical features, differential diagnosis and review of the literature. Surg Neurol 2003;60:219-225.

11. Ellis MJ, McDonald PJ. Acute epidural hematoma secondary to skull metastasis from esophageal carcinoma. Can J Neurol Sci 2007;34:491-493. 